\title{
The Reception of History and the History of Reception. On the Contemporaneity of Gerhard Richter
}

\author{
Julia Gelshorn \& Claudia Heide
}

To cite this article: Julia Gelshorn \& Claudia Heide (2012) The Reception of History and the History of Reception. On the Contemporaneity of Gerhard Richter, Art in Translation, 4:2, 185-210, DOI: $10.2752 / 175613112 X 13309377913089$

To link to this article: https://doi.org/10.2752/175613112X13309377913089

Published online: 28 Apr 2015.

Submit your article to this journal ऍ

山 Article views: 60 

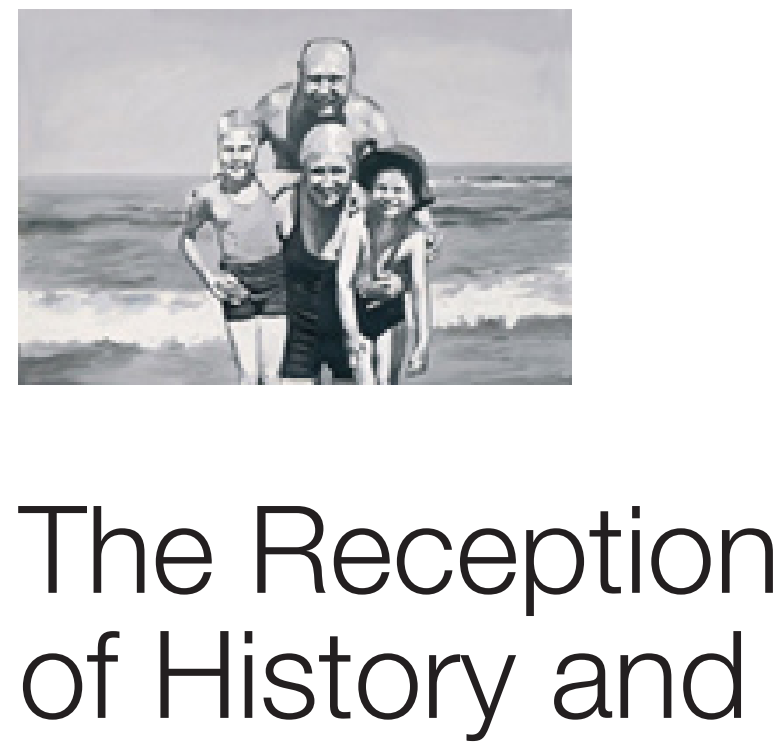
the History of Reception. On the Contemporaneity of Gerhard Richter

\section{Translated by Claudia Heide}

Originally published in German as "Geschichtsrezeption und Rezeptionsgeschichte. Zur Zeitgenossenschaft Gerhard Richters," in Dietmar Elger and Jürgen Müller, Sechs Vorträge über Gerhard Richter (Cologne: Verlag Walther König, 2007), pp. 71-95.

\section{Abstract}

The essay examines the reception of Gerhard Richter in a range of historical writing and exhibitions both in and outside Germany. Drawing on critical theories of reception, it is argued that the history of Richter's oeuvre is created as much by the artist himself-who actively controls the construct of his oeuvre-as by curators, critics, scholars, and biographers. The heterogeneity of Richter's work provided a basis for scholars to integrate Richter into the historical models of the neo-avant-garde and postmodernity. A return to narrative, iconography and, ultimately, biography in Richter's reception came with an increased art historical 
interest in German postwar art in relation to historical trauma. With the biographical turn, certain works by Richter became the subjects of almost contradictory narratives and stories and ultimately, deceptive witnesses of an exemplary German history.

KEYWORDS: Gerhard Richter, German art, art in the GDR, Dresden galleries, Caspar David Friedrich, historiography, neo-avant-garde, postmodern, postmodernity, German postwar art, postmodernism, Sigmar Polke, art criticism

\section{Introduction by Debbie Lewer (University of Glasgow)}

This text by art historian Julia Gelshorn first appeared in German in a 2007 collection of essays on Gerhard Richter published by the Gerhard Richter Archive. It is based on one of six lectures given at a symposium in Dresden to celebrate the artist's seventy-fifth birthday. The article is remarkable because it makes a rigorous, outspoken, and theoretically grounded critical challenge to the very many more conventional and often essentially celebratory accounts of Richter's practice and his significance. It takes strident issue with the dominant interpretations of Richter's work and his own self-presentation, in such a way that it raises important wider issues around the historicizing of recent art.

The essay deals with the reception of Gerhard Richter in a range of contexts, including by biographers in the GDR and former GDRtoday's Dresden-and internationally. It makes a critical dissection of the diverse cataloguing and archiving strategies employed by the artist himself. It highlights the marked degree of control exercised by Richter over the publication of text, image, and chronology pertaining to his own oeuvre. Especially interesting is the exposure of the extent and rationale for Richter's practice of the radical and extensive editing of his own interview texts after the event. The author then places these findings within a wider framework of the neo-avant-garde and postmodern with respect to historiographical practice. These latter sections of the essay open up the case study to make wider methodological points before returning, finally, to a critique of the use of biography in the construction of the public Richter. Because this is a near polemic revisionist reading of Richter, the target readership is one already familiar, at least to some degree, with Richter and his international standing and reputation (given Richter's recent ubiquity, this could be said to include almost anyone with even a passing interest in art). It is also very useful as a case study for considerations of methodology: specifically in relation to art biography, cataloguing practice, and canon formation in a postmodern context as well as more generally as an exemplary text underlining the critical importance of "reception history" itself. Within the large and growing field of "Richter studies," it is a highly unusual piece 


\section{Figure 1}

Gerhard Richter, Familie [Family], 1964, oil on canvas, 150 x $180 \mathrm{~cm}$. () Gerhard Richter 2011.

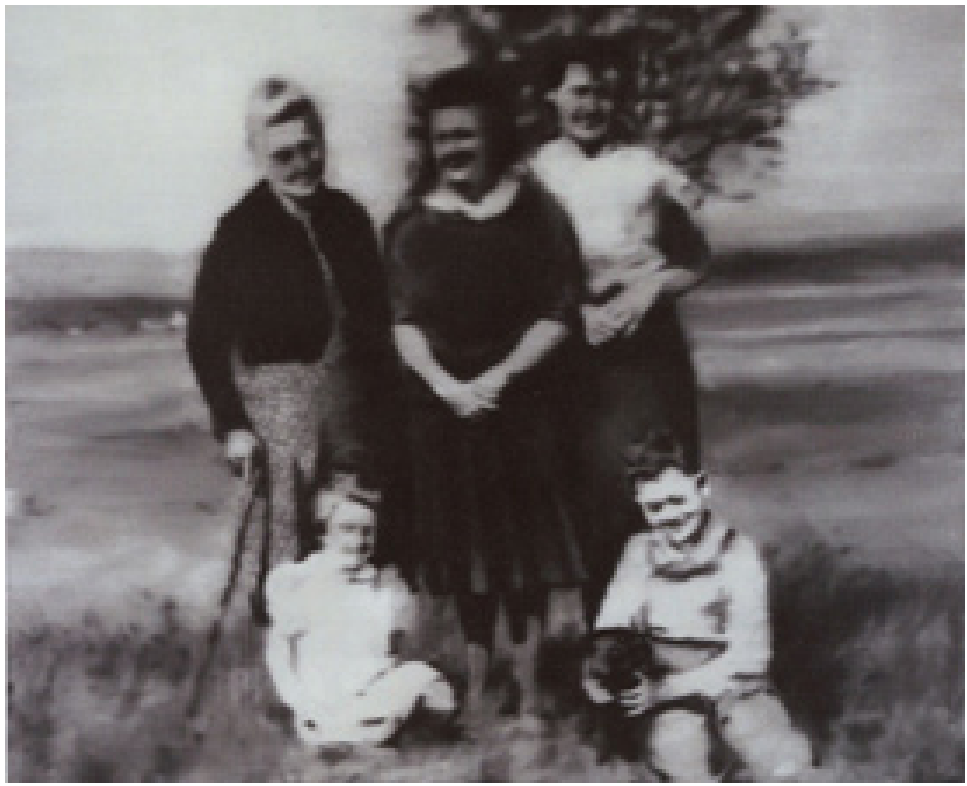

of writing - it is an argument that cuts, provocatively, right against the grain of the habitual apprehension and common celebration of Richter within the wider monographic literature.

\section{The Reception of History and the History of Reception. On the Contemporaneity of Gerhard Richter}

\section{Julia Gelshorn}

The circle has closed. History has followed an apparently logical narrative thread and is now returning to its point of origin: forty-three years after Gerhard Richter's departure from his native city of Dresden, the artist made a permanent loan of his works to the city, which at the time of the donation was plunged into turmoil by the ravaging floods of the River Elbe. Richter's works were destined to be displayed in the provisionally refurbished Albertinum in August 2004. ${ }^{1}$ The press solemnly celebrated this gift as Richter's "homecoming," his "choice for Dresden," and even as the "return of the absconded [instead of 'prodigal'] son" who for a long time had turned his back on Dresden, virtually denying his origins. ${ }^{2}$ This is a somewhat truncated version of a story that the Albertinum and the artist attempted to narrate in a much more neutral and seemingly objective form: Richter's loan works were not 
celebrated in a solo exhibition but presented as part of the lineage of the new masters and in direct dialog with the Dresden master Caspar David Friedrich. ${ }^{3}$ The point of origin and the end of the narration were already established by the exhibition title that featured on the façade of the Albertinum. The exhibition itinerary offered the visitor the option to go either directly into the rooms with Richter's loan works, or to follow a route which led chronologically through the collection of paintings via Romanticism, Impressionism, and Expressionism to the art of the GDR, and presented Richter as the singular manifestation of West German or rather pan-German contemporary art in the final three rooms. The narrative-based on a radically reductive selection of paintings from the museum's collection and with the focus on Richter as the point of culmination-attempted to present Richter's heterogeneous work as a direct digestion and reflection of the history of art presented in the previous rooms. At the same time, the spatial layout made it possible to create a direct connection between the two Dresden artists Caspar David Friedrich and Gerhard Richter, which was made explicit by the use of glass doors between a suite of rooms so as to provide a view of the two modern icons facing each other. The chronological exhibition itinerary was truly transformed into a circuit here: on the one hand Richter represents the end but also leads back to the beginning. Even though Richter's 11 Glasspanes, which had been originally intended to be installed in the viewing line, was replaced for technical reasons by a Gray Painting, the press, nevertheless, responded to this confrontation between Richter and Friedrich, stating that Romanticism and Abstraction mirrored each other. ${ }^{4}$ By juxtaposing the two artists, the curators indeed succeeded in visualizing a fundamental point in Richter's oeuvre: the relationship with a tradition of the Sublime, which is mirrored in exemplary fashion in Richter's Romantic, often paraphrased landscapes as well as in his abstract paintings. ${ }^{5}$ Werner Spies interpreted this notion of "mirroring" even more directly, suggesting that Richter and his works are "a mirror, the mirror of today's period" held up to the Romantic artist [Friedrich], and concluded accordingly that their artistic encounter in the exhibition would help to "decode" Richter's oeuvre. ${ }^{6}$

Spies's comment appears a logical conclusion from the display in Dresden: the experimental hanging of the paintings compared Richter with Friedrich, who had already been identified by art historical scholarship as an important reference point for Richter. In addition, the exhibition itinerary and the catalog attempted to tie Richter's oeuvre back to Dresden and to the collection of the Galerie Neue Meister: this is suggested, for example, by the juxtaposition of Richter's Secretary and Jean-Etienne Liotard's Chocolate Maid. ${ }^{7}$

The actual retrospective dependence of Richter's work on his place of origin remained, however, a blind spot. It is true that the exhibition showed GDR art, but both Richter's origin in Socialist Realism and 
generally his artistic beginnings in Dresden were overlooked, as was the question as to which of the presented "-isms" he could have actually accessed in 1950s Dresden. These omissions are, of course, the result of a conscious decision taken by the curators and by the artist himself, who played a significant part in the hanging of his own works and influenced to some degree the display of the works in the other rooms. ${ }^{8}$ Accordingly, the exhibition's aim did not consist in reviewing the past of an artist but in cautiously establishing a relationship between a West German artistic career and a historical tradition. The narrative that is offered in the process is a construct, which has to be recognized as such, for the reactions of the press have shown that the Albertinum was eagerly reviewed as a "memorial site" that would be able to break through the repressions and taboos of public debate in order to negotiate a chapter in the history and art history of a divided Germany. ${ }^{9}$

\section{On the Problem of "Contemporaneity"}

The history of an oeuvre and its significance is constituted, or even constructed, as much by the artist himself as by art criticism and scholarship, or by the entire "art world," to use a term coined by Arthur C. Danto to describe the interplay of these forces. ${ }^{10}$ Accordingly, the questions surrounding the understanding of an artist's work must also include questions regarding the histories that produced the work and the forces that contributed to it. If the above title explicitly draws attention to Gerhard Richter's contemporaneity, then this is not only in order to suggest that he continues to write and rewrite his story as our contemporary, but also to indicate that Richter has always been a contemporary - a contemporary of a historical situation and a contemporary of artistic and art historical expectations and ideas to which he has responded. The history of his oeuvre, therefore, came into being through a continuously oscillating relationship between its production and reception.

In 1994, the art historian Stefan Germer drew attention to this alternating relation in a short article-entitled "Die schwierigen Zeitgenossen" [The Difficult Contemporaries]—on the problems of historicizing contemporary art. Based on the assumption that meaning is always a construct-by the artist himself or by the reception of the works-Germer argued for a more flexible understanding of history. To this extent the enrichment of an oeuvre through contextualization, art writing, or reception should be considered as an integral part of the history of the oeuvre. ${ }^{11}$ In this sense Richter's appropriation and reception of history and art within his own work are closely tied up with the history of the reception of his work, especially since Richter's art is an exemplary self-reflexive art that keeps its own context in mind. The artist's comments, the historical context, art historical 
interpretations, and the development of the art market should not be considered as external conditions of the work, but rather as a meaningproducing network, as alternating acts of documenting, interpreting, and producing history.

Richter's works of art themselves, as much as their interpretations, are at the mercy of the demand for "contemporaneity." 12 In this respect the aim here is to demonstrate to what extent the changing zeitgeist and the corresponding expectations of art have led to different, and sometimes even to contradictory histories. ${ }^{13}$

Initially, however, we shall consider the constants: a number of key points in Richter's biography have been turned into the founding pillars for the interpretation of his work. After finishing his training at the Dresden Akademie and completing a number of commissions in the socialist realist style, the artist decided to leave the GDR in 1963 together with his wife Ema Eufinger. What ultimately inspired his departure was, according to his own comments, the visit to the second "Documenta" in Kassel and his confrontation with Informel painting in European and North American postwar art. Once arrived in West Germany, Richter embarked on a second training at the Kunstakademie in Düsseldorf. Influenced by his teachers, he engaged at first with Informel painting in the style of Fautrier, Dubuffet, and Fontana, but then literally made a tabula rasa with his painting Tisch [Table, 1962], founding a new body of work that is known today as the oeuvre of Gerhard Richter. Soon afterwards he disrupted his grisaille painting based on photographs and turned to the most diverse artistic concepts of painting, with the result that stylistic heterogeneity emerged as the major characteristic of the artist. These seem to be the "facts" that provide the key moments to all histories on Gerhard Richter's art.

Benjamin H. D. Buchloh, whose writings and interviews have made a fundamental contribution to Richter's reception, emphasized in his dissertation on the artist that his "peculiar biographical circumstances" turned Richter into a figure with a double identity. Richter, after all, had first trained and worked within the context of communist East Germany, and was then confronted with West German capitalist consumerist society. For Buchloh, therefore, Richter is an exemplary representative of a divided heritage. ${ }^{14}$

For the critics this double identity was all the more mysterious and difficult to research since there was hardly any evidence for the GDR's impact on Richter. Upon his departure from the GDR not only was Richter forced to abandon all the works that he had created during his time at the Akademie of Dresden, but he was also extremely economical in publishing these works, even though they had been carefully documented through photographs. ${ }^{15}$ Only occasionally could an early self-portrait or a detail from his mural (later painted over), the degree work for the Dresden Hygiene-Museum, be found in some publications. It was only with the biography by Dietmar Elger of 2002, the biographical-journalistic 
novel by Jürgen Schreiber on Richter's family (2005), an article by Jeanne Nugent included in the exhibition catalog of the Getty Museum (2006), and another Getty publication on Richter's Early Work that a few more early works were added to those already known. ${ }^{16}$

The same situation applies to Richter's early West German work created within the ambit of the Kunstakademie in Dusseldorf, and this is even more remarkable for the work did not get lost but was set on fire by the artist himself in 1962 after a first and last public presentation. ${ }^{17}$ Nevertheless this phase, which was inclined toward Informel painting, was also recorded by the artist through photographs. Still in the same year he initiated a new phase with the work Tisch [Table], thereby officially founding the beginning of his West German artistic career, and thus the history of Gerhard Richter's art.

\section{Anti-Linear Historical Constructs}

While any artistic beginnings tend to remain diffuse, early works offer us insights into an artist's first cautious efforts and the later artistic development toward a mature style. Richter, however, deliberately obscures this early phase and turns it into a blank space. ${ }^{18}$ From the outset, any attempts to study the stylistic or iconographic developments of the artist are undermined by Richter and his concept of painting. The totality of his oeuvre is presented instead through the numbering of his works all the way through from the beginning. The first picture index [Bildverzeichnis] clearly confirms this claim. Hubertus Butin and Catharina Mancanda have shown that, in aesthetic terms, Richter turns to practices of conceptual and minimalist art, listing his works in a bureaucratic manner, apparently without subject, by number, title, year, and measurements. ${ }^{19}$ Yet, the fact that his own index is turned into a work of art as an offset print points to a conscious act of artistic self-representation on the one hand, and on the other, demonstrates the artist's clear attempt to control his own reception. As a work of art, the Bildverzeichnis reveals Richter's own self-construction and artistic position and, at the same time, his demand to establish personally the documentation and the historical chronology of his works. The artist thereby takes on genuine art historical tasks. ${ }^{20}$

Under the guidance of the artist the index then appeared for the first time in full and illustrated form with proportionately sized color reproductions in the exhibition catalog of the major Richter retrospective of 1993, which as a fictive miniature museum offered the viewer a chronological parkour through the work. ${ }^{21}$ The small-sized illustrations not only served a pragmatic purpose-the pictures can be easily located-but have above all a conceptual effect: in the fashion of a sales catalog for artistic styles and forms, each double page exposes the heterogeneity of the works at a single glance. The Bildverzeichnis with its individually numbered works not only appears as a complete opus but 

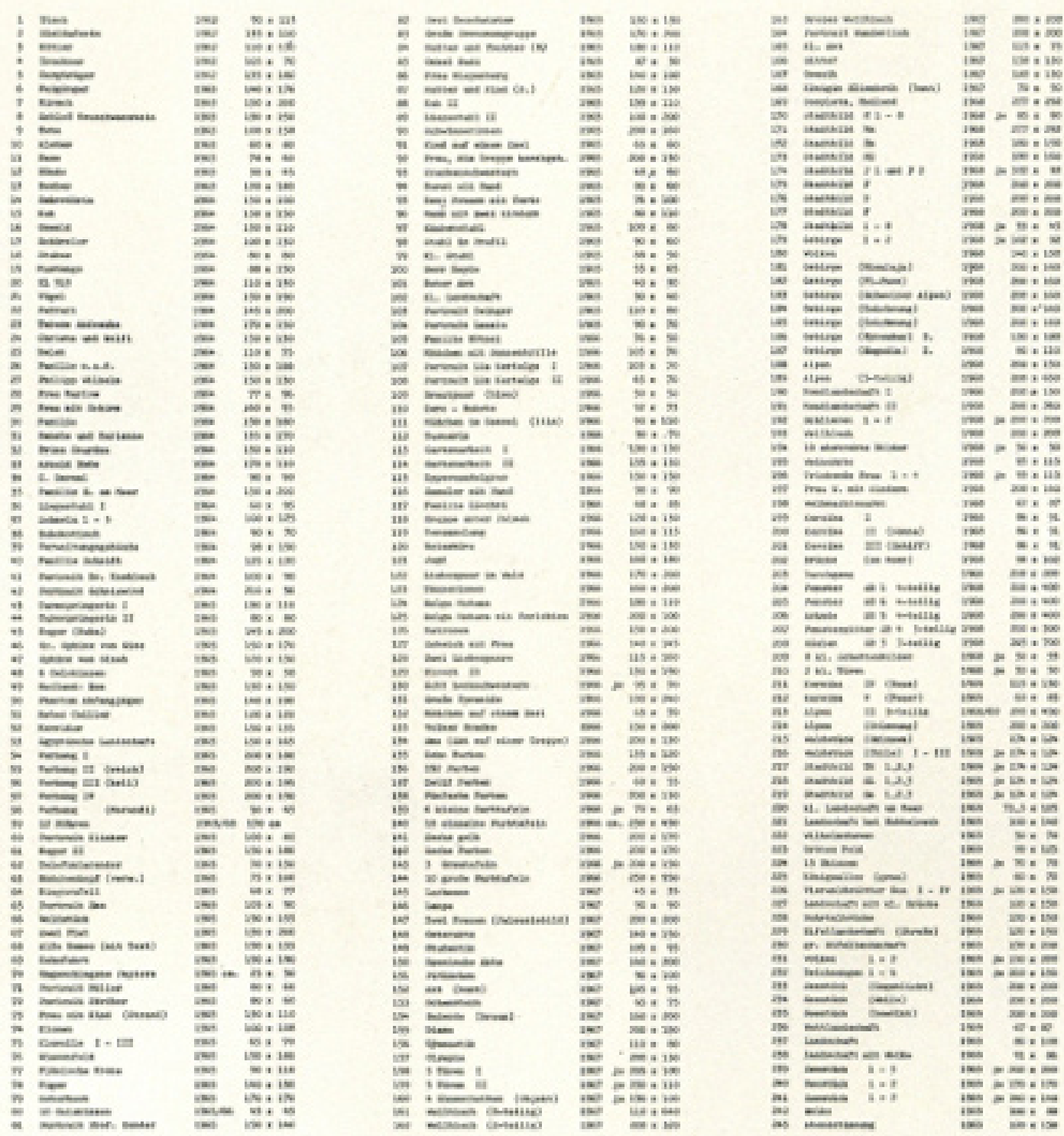

Figure 2

Gerhard Richter, Bildverzeichnis [Picture Index], 1998, 83 × 68cm. @ Gerhard Richter 2011.

also provides a general overview of all the orchestrated changes within the work.

Independently from Richter's index, Erik Verhagen argued that the artist deliberately challenged certain works or groups of works of art that appeared to suggest a change in the oeuvre, by adopting an opposite painterly position at the next stage so that he could not 
be pinned down to a defined position or development. ${ }^{22}$ For instance, Richter's Akt auf der Treppe [Nude on a Staircase]—his first work to be based on a colored photograph and which was discussed for its classical impetus-was followed by his first Color Chart. The controversial RAF cycle 18 October 1977 was countered with the intimate, private portrait of Betty in order to undermine the label of "political painter." Whether the motivations for Richter's sequence of works really match the ones given by Verhagen is subject to further debate. It is, however, important to note that the illustrated index offers an ideal possibility to visualize and document such changes in the work, even beyond the time of the production of the paintings. In this respect Robert Storr has suggested that the index of works ultimately represents a construct, which proposes a partially fictive chronology. ${ }^{23}$

One of the last pages of the index reveals this construct once again: the painting Fenster [Window] classified as number 880-1 and dated 2002, corresponds exactly to number 205 which is dated 1968. Did Richter copy his own work thirty-four years later, as the catalog with its indication of the year 2002 seems to suggest? Or, did he simply paint exactly the same painting again in 2002? If this was the case, then the artist specifically reminds us, through his illustrated catalog, that his work should not be considered in terms of a linear development, even though the abstract paintings have clearly gained majority over time. The alternative thesis, which is debatable, would be that Richter only decided in 2002 to integrate an old variant of the window series, which might still have been in his studio, into his index. In this case, the indication of the year 2002 is deliberately misleading and comparable to the procedure with the ready-made, an object that already exists and only subsequently declared by the artist to be a work of art. While the index does not offer an explanation, it is important to note that even after forty years of working in West Germany, Richter strategically and rigorously presents his own history as anti-linear.

In this respect the oeuvre catalog is widely understood to be a vehicle for self-documentation, which is further complemented by the Atlas, the collection of photographs, collages, and sketches. ${ }^{24} \mathrm{~A}$ similar procedure can also be detected in Richter's comments in his notes, interviews, and own texts. What Richter once presented in an openly ironic way in his early artistic texts though-partly in collaboration with Sigmar Polke-is masked in later interviews, although it is equally present. Some of Richter's comments on the themes of his paintings, for example, show that he entirely contradicts himself within a period of two years: "I do not favor any particular pictorial themes"; or "For me, there is certainly a hierarchy of subject matters-turnip and Madonna are not equal, not even as objects of art"; or "Do you know what was great?-To notice that how such a ridiculous and absurd thing as the simple copying of a postcard can result in a painting. And the freedom to be able to paint what is enjoyable. Stags, airplanes, queens, secretaries." Yet, finally, he stated again: "I am only concerned with the subject [Gegenstand], otherwise 
I would not put so much effort into the choice of the sujet, otherwise I would not paint it at all." 25 At a later stage, by which time Richter's painting already comprised a much wider spectrum, he insisted: “My paintings are subject-less; like objects they are objects themselves. They do not have any content, significance and meaning, just like objects or trees...," only to declare soon afterward the exact opposite: "It is the most natural thing in the world to respond to distinctive events. It would be absurd if precisely that which concerns us most were taboo. Then we would only produce trivial things." 26

When interviewing Richter in 2002, Robert Storr referred to such statements in examining Richter's interest in specific themes. Storr, therefore, was demanding a confirmation from Richter when he referred to one of the artist's earlier statements: “After all, you have said: 'The Mona Lisa is not a turnip.' There are hierarchies of subject matter; a cow, which you have also painted, is not a 1940s fighter plane or a 1960s fighter plane." ${ }^{27}$ Richter's reply refuted these assertions and fixed views, yet in the most revealing way: "I never knew what I was doing. What am I supposed to say now? Now I could lie here, like I am on an analyst's couch, and try to figure out my actual motives with the help of others and make sense of them. Is that what you want now?"28

The selected extracts are just arbitrary examples from Richter's production of texts, which reveal that here, too, the artist's stylistic progress has been staged so that he cannot be associated with one particular position or even a conceptual development. On the one hand, this strategy must be interpreted as a play on the concept of "The Death of the Author," as it was theorized by Roland Barthes and Michel Foucault at the time, that is as a decentralization of the artist as a subject. On the other hand, however, it reveals itself in many places as a paradoxical confirmation of the artist's power and authoritative gesture which precisely contradict his orchestrated disappearance. ${ }^{29}$ I do not intend to expand on these paradoxes here and would like to suggest instead that Richter's writings and comments function as a "parallel phenomenon" to his works of art insofar as they undermine a linear history, take up discursive positions like ready-made paintings, and orchestrate as well as conceal artistic breaks behind an apparent authenticity. ${ }^{30}$

This proprietorial attitude over his own verbal expressions and hence his own history is also apparent in the accuracy with which Richter edits his interviews: a transcript of a conversation between an art historian and the artist, if examined, turns out to be a carefully reworked text. As an example, Dieter Schwarz has kindly offered the heavily edited transcript of his interview with Gerhard Richter, which took place on June 26, 1999 on the occasion of the exhibition of Richter's watercolors in the Kunstmuseum Winterthur. ${ }^{31}$ The typescript of the original conversation was sent by fax back and forth, and annotated with handwritten corrections by Gerhard Richter, while Schwarz himself rearticulated certain questions. ${ }^{32}$ This shows that Richter corrected, 
rearticulated or entirely replaced nearly all his comments. Other segments of the conversation were deleted but not replaced, and new transitional passages were created retrospectively. It is striking that the written corrections simulate an oral immediacy that is characteristic of free speech. The resulting impression of a conversational situation where ideas and comments develop spontaneously is actually a fabrication, which not only has been carefully planned and reworked, but through decisive insertions and changes has grown into a fictive construction that is accepted by both parties. ${ }^{33}$

This case in point does not, of course, exemplify a unique practice pertaining to Richter alone, but is rather a common procedure among many artists and other public figures. And yet, it clearly shows the extent to which an artist's interview should not simply be used as a source text for our writing of history, but must be read and interpreted as a construct created by the artist.

Already early in his career Richter began to systematically document his work and to control access to this information: This started with his first photographic record of the work dating from his first two periods, which reached the public only occasionally. It continued with his oeuvre catalog, his Atlas and not least the many interviews, notes, published letters, and texts. This seems to be one side of the story, which itself stands in an alternating relationship with the demands of the art world on the artist and the fulfillment and undermining of expectations. How then has art history dealt with the artist's own historiography?

\section{Neo-Avant-Garde and Postmodernism: Historical Models of Reception}

One of the most influential interpretations of Richter's oeuvre, namely Benjamin Buchloh's, takes the heterogeneity of his work as a starting point in order to integrate Richter into a clearly defined historical model. Buchloh's historical model is based on Peter Bürger's distinction between the historical avant-garde from 1910 to 1925 and a European postwar neo-avant-garde that returns to its earlier practices. ${ }^{34}$ Accordingly, Buchloh interpreted the constant changes in Richter's painterly positions, made visible in the catalog of the oeuvre, as an artistic repetition of the paradigms of the avant-garde, of which the specific manner of the reception and different interpretation is marked by the prefix "neo." For Buchloh, the avant-garde paradigms, which themselves already commented on and undermined a tradition of painting and which were now taken up again by Richter in various ways, fell into four categories. The first is the legacy of photomontage and collage, which Buchloh analyzes above all through Richter's Atlas. The second category is the reduced painterliness of monochrome painting and the grid. Third comes classicism, which Buchloh precisely interprets as anti-modern and, finally, we have gestural painting as a fourth category. The panorama of 
Richter's painterly beginnings was interpreted by Buchloh as a working through of the rhetoric of painting, but which demonstrates the actual loss of historical categories and functions. ${ }^{35}$ Accordingly, Richter's painting reveals the impossibility for authentic painting in the postwar period. Other scholars have criticized this interpretation as reductive and reproached Buchloh for using Richter's work merely to fit his thesis. ${ }^{36}$ Opposed to this, Hubertus Butin, for example, suggested that Richter's adaptation of avant-garde paradigms to the "conditions of his own contemporary gaze" did ultimately result in "new and individual images." 37

Buchloh's historical model of the neo-avant-garde contrasts with theories of postmodernism, which were paramount to the historical interpretation of Richter's work by Buchloh's American colleagues. This model, like that of the neo-avant-garde, also referred to Richter's repetition of images and the resulting heterogeneity. Yet, it should be remembered that the labeling of Richter's work as "postmodern" derived from two distinct theoretical models: the theoretical concept of posthistoire [posthistory] created by Arnold Gehlen pessimistically assumes the end of all innovations and historical possibilities, ${ }^{38}$ whereas the concept of the postmodern, as represented mainly by Jean-Francois Lyotard, rather optimistically declares the end of the idea of a unitary history and its totalizing meta- or master narratives. Frederic Jameson, in contrast, established a radical break between modernism and postmodernism through the "end of ideology, art, or social class; the crisis of Leninism, social democracy, or the welfare state, etc. etc." In his understanding, postmodernism is conceived as a "cultural dominant" necessarily bound up with postindustrial and multinational capitalism. ${ }^{39}$ Wolfgang Welsch, in his study of the definition and history of postmodernity, specifically points out that the theoretical concepts of posthistoire and postmodernism are often used in an identical fashion, although they do not have anything to do with each other. ${ }^{40}$ Nevertheless, in the attempt to analyze contemporary phenomena such as the repetition or plurality of forms of expressions, the two concepts have often been merged in the process, although they are based on two fundamentally different end-visions - the end of innovations on one hand, and the end of great histories on the other. Horst Bredekamp has shown that the conflation of different ideas of the "end" under the paradigm of postmodernity finds its origin in Hegel's philosophical idea of the end of history, ${ }^{41}$ and is expressed in numerous other end-visions: in the "death of the subject," "the death of the author," "the end of the book," and in this respect also in the "end of art," and more specifically, the "end of painting." ${ }^{22}$ That Gerhard Richter along with many other artists was used to illustrate these verdicts of "the end," rather than being analyzed through them, emerges from various interpretations which identify the artist with so-called "post-narrative" and "post-historic" art. Danto even argues directly for the conflation of the terms "post-narrative" and "post-historic" in order to describe the state of art "after the end of art." 43 In the period after this, narrative painting survived by adapting to new 
circumstances and integrating the plurality of the art world within its forms. ${ }^{44}$ On the basis of Richter's declaration that all media and styles are equally legitimate and his rejection of a "certain ideal of purity," Danto explicitly identifies Richter with those artists who "most aptly exemplify the post-historical moment." 45

In contrast to this, Douglas Crimp quotes Richter's statement that painting is "pure nonsense" as evidence for, and in endorsement of, the end of painting itself. In relation to postmodernism, he discusses a turning-away from painting and instead a turn toward photography and non-museological art. ${ }^{46}$ Craig Owens, another apologist for postmodern art, compares Gerhard Richter's demonstration of conceptual incoherence and stylistic heterogeneity with the photographic role-playing of Cindy Sherman, who stages the disappearance of the author through her repetitions, just like Richter does. ${ }^{47}$ This last comparison alone gives the impression of a historical model being forced upon an artistic practice, instead of shedding light on the work itself.

Richter's edition Übersicht [Survey] of 1998 (Figure 3) can be read precisely as a counterpoint to the appropriation of such historical models: the diagram shows a long line of tradition of Western culture from antiquity to the present day. The Übersicht presents a list of a selection of artists, architects, composers, philosophers, and writers in chronological order, including Richter himself in the section of art. Dieter Schwarz has proposed the thesis that Richter presents here not so much a personal selection, but rather a collective consensus that inevitably becomes weaker in the present time, with the consequence that the number of names increases from the left to the right side. ${ }^{48}$ In any case, Richter positions himself as an heir of a chosen family that consists of his own created canon of important artists. By seizing the myth of a survey in his Übersicht, he shows that he is indeed interested in a tradition. While Danto sees the end of history confirmed by the idea that the "canon... is closed," 49 Richter actually places himself and his contemporaries into such a canon and history without any reservation. And yet, history must not be equated with a purposeful processing of stylistic development, and this is made obvious through his own oeuvre index. To this extent, we can agree with Jeanne Nugent, who paradoxically observes a simultaneous deconstruction and reconstruction of history in Richter's work. ${ }^{50}$

\section{Against a Rhetoric of Painting: The Return of the Subject}

While the historiographical models of postmodernity and the neoavant-garde are based on stylistic heterogeneity and arbitrarily chosen motifs, a detailed discussion of the choice and meaning of the subjects in Richter's work began at the latest in 1988 with the exhibition of 


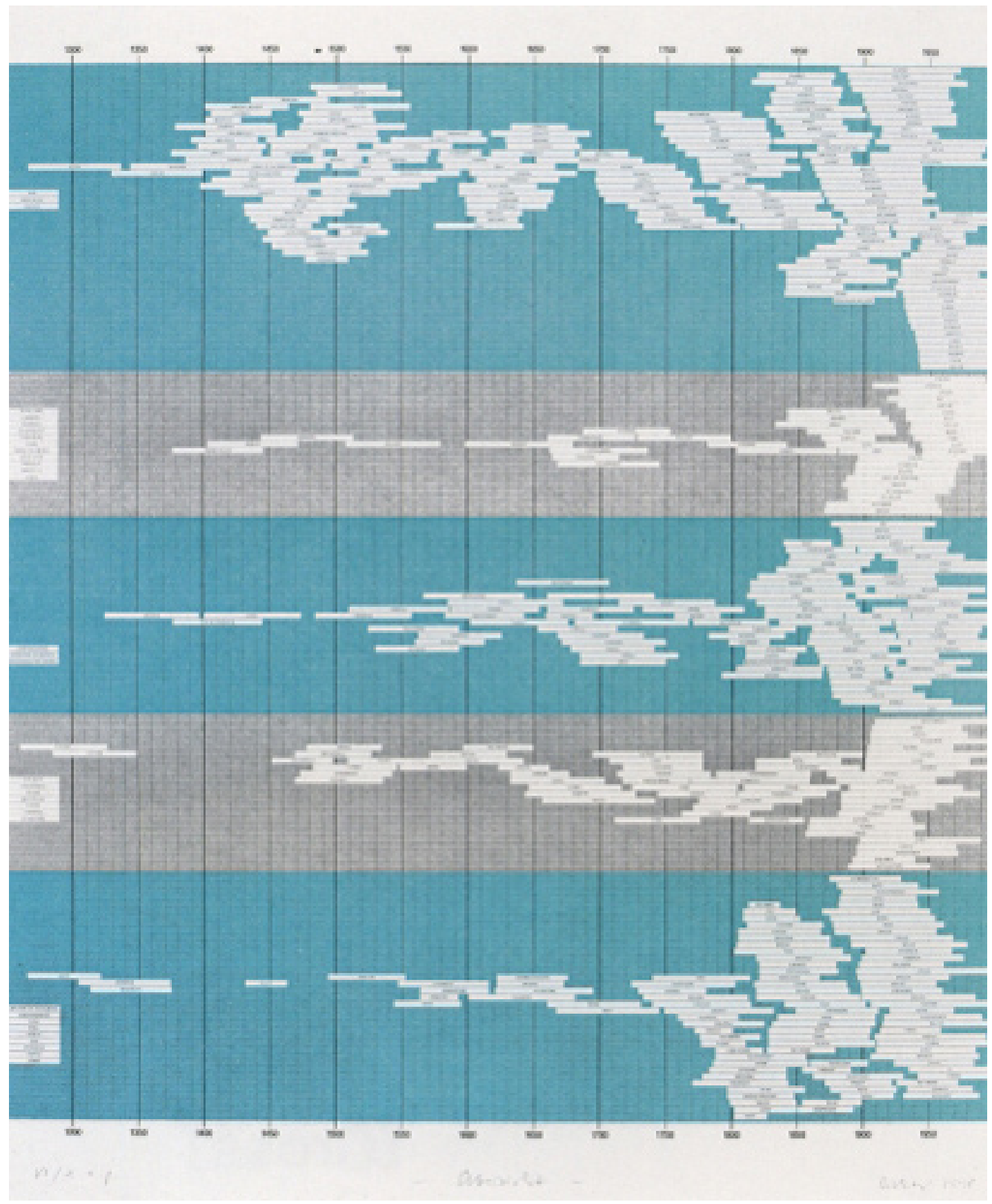

Figure 3

Gerhard Richter, Übersicht [Survey], 1998. (C) Gerhard Richter 2011. 
Richter's RAF cycle 18 October 1977. Richter had already juxtaposed politically loaded paintings, such as the portrait Hitler or the Phantom Abfangiäger [Phantom Fighter Planes], with trivial subjects like Eisläuferin [Ice Skater], the painted advertisement of a washing stand or the blurred image of the dome of Milan. Now he focused on repressed themes from German history in a comprehensive cycle. Consequently the art critics felt alienated as much by Richter's choice of the subject matter as by his ambivalent way of representation. ${ }^{51} \mathrm{It}$ is significant that the explicit attention to Richter's motifs and iconography and hence the move away from Buchloh's "rhetoric of painting" was tied to the North American reception of the RAF [Red Army Faction] cycle by Robert Storr. Following the single 2000 exhibition of the RAF cycle (purchased by MOMA in 1995), Storr also used it as a center point in his great American retrospective of Gerhard Richter in 2004 and 2005.52 On the one hand Richter was presented to the American public as a responsible German artist, whose success could be justified by his critical and diverse engagement with the past of his native country, which was also a major theme in other parts of the exhibition and the catalog. On the other hand, Storr finally encapsulated Richter's oeuvre in the term "an iconography of the everyday." ${ }_{33}$ Storr was primarily interested in the themes and the painterly refinement in each individual masterpiece, and not in the hitherto dominant generalization of the paintings that classified them into larger groups.

This change in Richter's reception is not due to Storr's interpretation alone, but must be ascribed to the lasting painting boom that began in the 1980s, especially in German painting, and to the return to narrative and iconography on the one hand and to a new interest in painterly modes on the other. The persistent discourse involving a historically obsolete painting and the prescription of avant-garde paradigms seemed outdated in the face of two new phenomena: the abundance of antiaesthetic conceptual art and a "craving for pictures," to use Wolfgang Max Faust's description. ${ }^{54}$ In addition there was an increased art historical interest in the question as to how German postwar art dealt with its historical trauma. ${ }^{55}$ The RAF cycle did not only react to these debates on suppression and memory but also triggered them in relation to Richter's entire oeuvre, thereby drawing attention to the content of the paintings. ${ }^{56}$

This attempt to come to terms with history revived an interest in the subject of the artist himself, which is reflected in the biographical projects on Gerhard Richter. Dietmar Elgar authored a comprehensive biography of Gerhard Richter, while others, such as Hubert Butin or the curators of the exhibition "Wie alles began" ["How It All Began"] of 2004, also centered their investigations upon the biographical aspects of Richter's career and work. ${ }^{57}$ 


\section{The Biographical Turn: From the Death of the Author to the Life of the Artist}

This biographical turn in the reception of Gerhard Richter is evident in a group of works that perfectly illustrates how certain works by Richter became the subjects of almost contradictory narratives and stories and ultimately, deceptive witnesses of an exemplary German history. The group of works in question may be summed up with the keyword "family pictures." This term has a double meaning in Richter's work: on the one hand it simply describes the works, which have arisen from Richter's documented collection of family photographs included in his Atlas (Figures 4 and 5). On the other, this group of works overlaps with paintings after photographs that do not depict any family but Richter's own family.

In his seminal essay on the Atlas as an "anomic archive," Buchloh hypothesizes that the photographs of Richter's family members had served the artist as a starting point to reflect on the relationship between photography and historical memory. According to this, the power of the mnemonic connections to the past and their lasting effects on the present are best confirmed as material processes through a reflection on the family picture. By confronting these panels with others that showed the most diverse press photographs as a confusing heterogeneous ensemble, Richter juxtaposed the private construction of identity through the family photograph and the public construction of identity through media culture. What is represented by Richter, according to Buchloh, is the memory of an archaeology of pictorial and photographic registers, which, in short, reveals the condition of German suppression in the banality and heterogeneity of the images. ${ }^{58}$ Photography, including family photography, is understood here as a medium that was used to physically implement and transmit the historical suppression. According to Buchloh, given the historical suppression during the postwar period, Richter had to ask himself to what extent images of memories were possible at all and at the same time dealt with the problem of whether a painting was actually still feasible in consideration of photographic mass culture. In Richter's art, the examination of the uses and function of photography therefore has to do with collective memory. For Buchloh, the anomic and hence arbitrary order of the photographs reveals the randomness of their selection and the banality of their motifs. This use of photographs based on avant-garde collage techniques is to be understood as an expression of the decentralization of the subject. The fact that the family photographs came to a great extent from Richter's private family albums only plays a minor role in Buchloh's argument: it is only relevant with regards to the question as to whether Richter had been motivated by the personal loss of a familiar environment. ${ }^{59}$

In Robert Storr's interpretation, by contrast, the photographs of Richter's family underwent a transformation from collective souvenir 


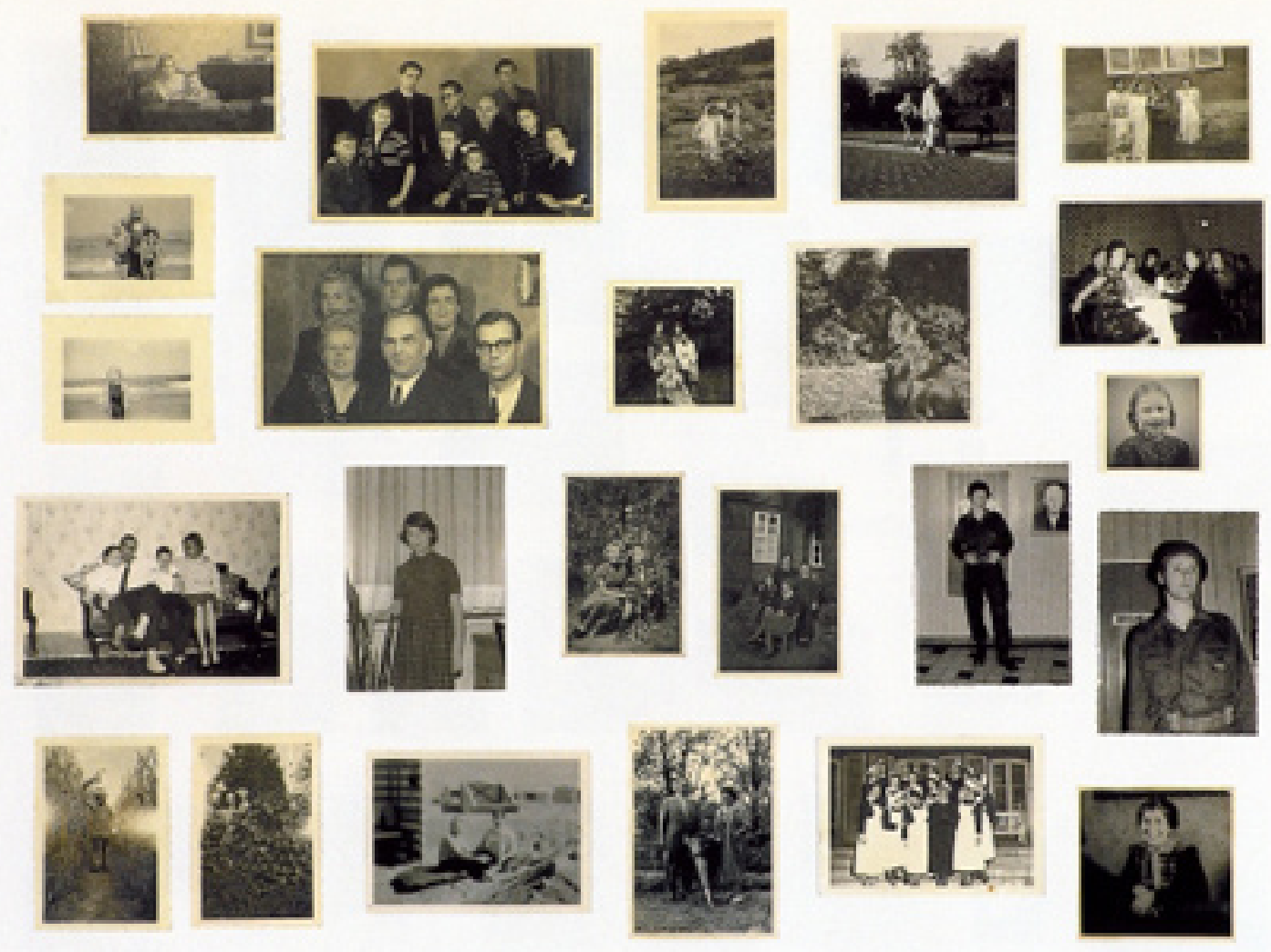

Figure 4

Gerhard Richter, Atlas, plate 2 (album photos). (c) Gerhard Richter 2011.

pictures to testimonies of an individual history. These individual histories, embodied by Richter's relatives, were interpreted by Storr as exemplary in the sense that they showed a collective heritage ${ }^{60}$ For instance, Richter's Onkel Rudi in Wehrmacht uniform is representative of a generation who voluntarily contributed to self-destruction and the destruction of millions of lives. By contrast Tante Marianne (Figure 6), who is seen as a young girl with the artist as a baby, is, according to Storr, a counter-figure to Uncle Rudi, because as a schizophrenic she fell victim to the national socialist program for euthanasia. Finally, Richter indirectly painted the murderer of Aunt Marianne in the portrait Herr Heyde, since he largely directed the euthanasia program under Hitler. Storr does not just look for a narrative in individual works, but connects individual works that are scattered over Richter's whole oeuvre to 

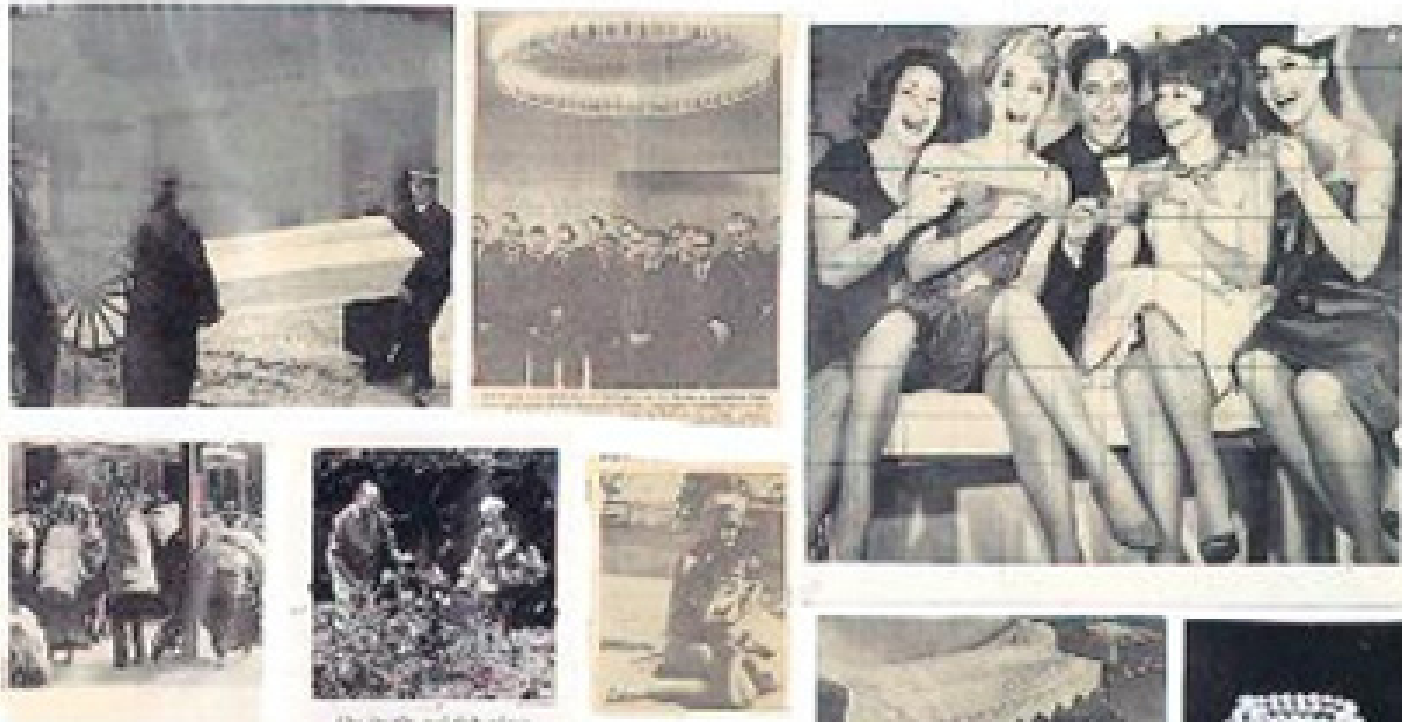

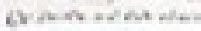
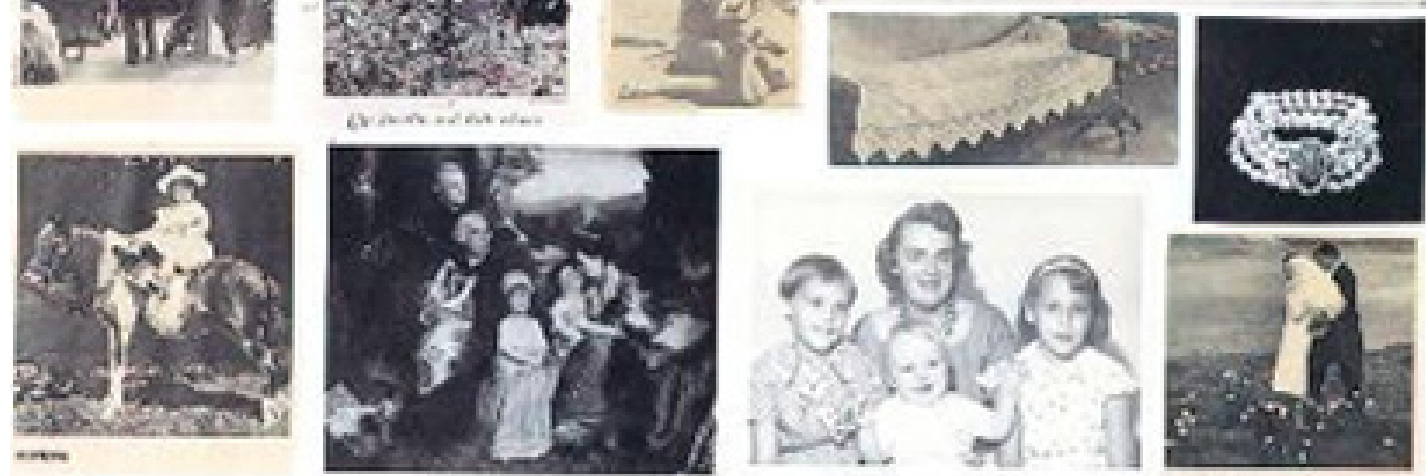

Figure 5

Gerhard Richter, Atlas, plate 9 (newspaper photos). (c) Gerhard Richter 2011.

form a coherent narrative. As Storr sees it, Richter tells exemplary stories through his images, and thereby closes the fracture which still runs through German culture due to the denial of the past. ${ }^{61}$ To what extent the images really tell these stories is not questioned by Storr.

The connection between private and collective history culminated in the journalistic novel by Jürgen Schreiber published in 2005 on the "drama" of the Richter family. ${ }^{62}$ The author covers here the story of Aunt Marianne in all its frightening and sad details and discovers in the process not only the symbolic murderer Heyde, but also the person who actually ordered her sterilization, and, as fate would dictate, who turned out to be nobody other than Richter's ex-father-in-law, Dr. Heinrich Eufinger-facts that were unknown to Storr. Richter had eternalized him in his entirely unpolitical portrait Familie am Meer [Family at the Seaside] (Figure 7), together with his first wife as a girl wearing a bathing cap. 


\section{Figure 6}

Gerhard Richter, Tante Marianne, 1965 , oil on canvas, $100 \times 115 \mathrm{~cm}$. (c) Gerhard Richter 2011.

\section{Figure 7}

Gerhard Richter, Familie am Meer, 1964, oil on canvas, $150 \times 200 \mathrm{~cm}$. (C) Gerhard Richter 2011.
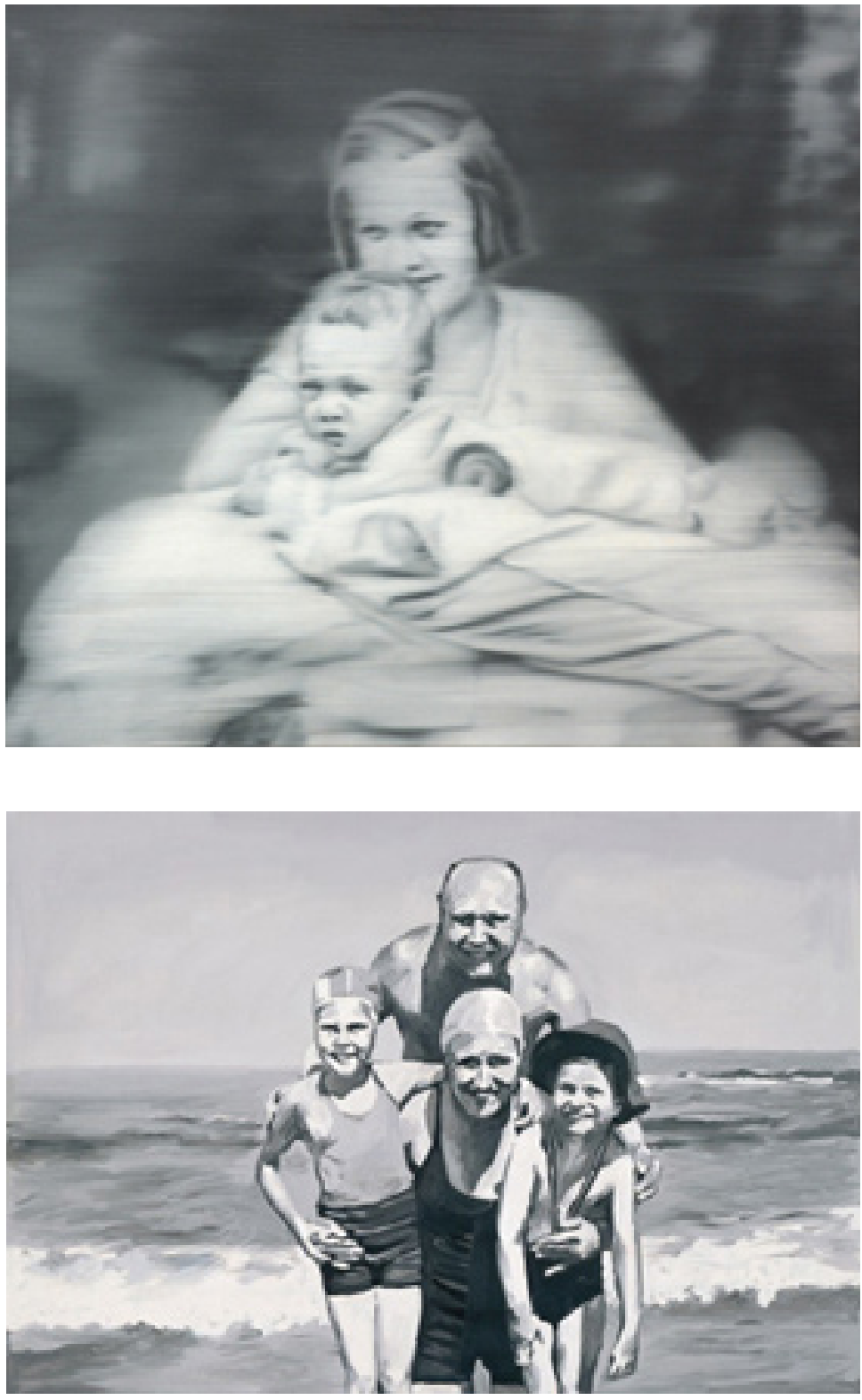

The discovery of this connection finally leads Schreiber to describe the portrait of Herr Heyde, which openly thematizes the Nazi crime, in Freudian terms as a "concealed memory" that represents a group of blocked issues for Richter. ${ }^{63}$ This inference of an apparently biographical impact on the work is a fatal error, and does not rely on any art historical line of argument either. In Schreiber's biography, Richter's paintings 
are reduced to being illustrations of history on the one hand, and on the other they are explained through history in an arbitrarily constructed manner. For instance, Richter's artist's book War Cut, on the Iraq War, produced fifty-nine years after the destruction of Dresden-which Richter only experienced from a distance-shows, according to Schreiber, "the colors of death" rooted in Richter's "experience of the abyss" at Dresden. ${ }^{64}$

Schreiber's reading, which seems to open a radically different perspective on this "family gang," 65 argues that the picture of the German disaster emerges from the covering colors. This is problematic as it confuses the form and content of the work, and does not seriously consider the context in which Richter's family pictures were made. Richter's insertion of Aunt Marianne in his oeuvre catalog already shows that the connections between the political paintings, as proposed by Robert Storr, tell an entirely different story from the one told by the artist himself in his oeuvre catalog. In addition, the fact that the painting Tante Marianne was still entitled Mother and Child in Richter's first Bildverzeichnis, even though he knew very well that the image showed himself with his aunt (in the same way that the Familie am Meer does not represent a father, mother, and children, but a patient of Eufinger and her son), ${ }^{66}$ suggests that Richter was studying the genre of the family portrait and its artistic and photographic tradition in a pictorial way rather than engaging with the personal history, which is veiled behind the pictures. Familie am Meer and Tante Marianne remain as anonymous as the nameless family of 1964, which once again shows Richter's family and himself, or the pictures of families that have names but are equally stereotypical: the families Wende (1971), Liechti (1966) or Ruhnau (1968). However, at the same time, Richter's deindividualization of his works indeed provoked their reindividualization, and thereby the search for a story in and behind the pictures.

It is perhaps timely that Buchloh's reading of photographic media in terms of the suppression of the past has been counterbalanced by Storr, who sees the photographs in terms of individual biographies, such as those of Aunt Marianne and Uncle Rudi, who are at the same time representatives of a generation. ${ }^{67}$ Jürgen Schreiber, however, turns Gerhard Richter himself into this figure: the "painter from Germany" is declared a collective representative, who embodies and commemorates our entire history.

This conception of Richter was once again accentuated by the 2004 exhibition in Dresden and the installation of the Gerhard Richter Archive in Dresden: as Jürgen Becker wrote in the exhibition catalog, Gerhard Richter should be seen retrospectively as "a Dresden painter," even though, as Becker admits, he never really was a Dresden painter and even though the cities on the Rhine may claim him in future as the "Dusseldorf painter" or a "Cologne painter." 68 It is only against this background, however, that Richter can become the exemplary "painter of the divided and reunited Germany” within Dresden's construct of history, 
and thereby a kind of collective singularity. With the newly established Gerhard Richter Archive, the memory, the neglect, and displacement of Gerhard Richter will be transferred into a public and collective act. And so Richter himself has engaged with his own history and increasingly endorses the rehabilitation of, and research into, his hitherto neglected early body of work. ${ }^{69}$ What the individual Richter himself does not remember will therefore undoubtedly be retrieved through academic research.

\section{Notes}

1. Forty-three works were on display, including eleven from private collections and thirty from the artist's collection, which were put on permanent loan to the Galerie Neue Meister. One work included in the exhibition is owned by the Galerie Neue Meister, and another one is on permanent loan from the German state. On the exhibition of 2004, see: Gerhard Richter im Albertinum Dresden, exhibition catalog (Dresden: Galerie Neue Meister, Albertinum, Staatliche Kunstsammlungen, 2004).

2. Tobias Rüther, "Heimkehr. Der Künstler Gerhard Richter besucht seine Werke in der Dresdner Galerie Neue Meister," Frankfurter Allgemeine Sonntagszeitung, August 22, 2004; Werner Spies, "Die Dresdner Entscheidung. Heimkehr des entflohenen Sohnes: Gerhard Richter stellt seiner Heimatstadt ein Konvolut seiner wichtigsten Bilder dauerhaft zur Verfügung," Frankfurter Allgemeine Zeitung, August 21, 2004; Heinrich Wefing, "Der Stadt den Kopf nach vorne drehen. Die Dresdner Galerie Neuer Meister wird mit Werken Gerhard Richters wiedereröffnet," Frankfurter Allgemeine Zeitung, August 20, 2004.

3. This was also the case with the later presentation of works from Dresden at the J. Paul Getty Museum in Los Angeles: From Caspar David Friedrich to Gerhard Richter. German Paintings from Dresden (Los Angeles: The J. Paul Getty Museum, 2006).

4. Patrick Bahners, "Der übermalte Schrecken," Frankfurter Allgemeine Zeitung, September 18, 2004.

5. For a more detailed discussion, see Julia Gelshorn, "Bildtopologien bei Gerhard Richter und Sigmar Polke," Kritische Berichte, 34, no. 2 (2006): 49-62.

6. Spies, "Die Dresdner Entscheidung...."

7. Gerhard Richter im Albertinum Dresden, p. 1.

8. This information was provided by Ulrich Bischoff during a conversation on March 8, 2005.

9. Bahners, "Der übermalte Schrecken."

10. Arthur C. Danto, "The Artworld," Philip Anderson (ed.), The Philosophy of the Visual Arts (New York: Oxford University Press, 1992), pp. 426-433. 
11. Stefan Germer, "Die schwierigen Zeitgenossen. Über die Probleme der Historisierung aktueller Kunst" (1994), in Julia Bernard (ed.), Germeriana. Unveröffentlichete oder Übersetzte Schriften von Stefan Germer (Jahresring 46, Jahrbuch für moderne Kunst, Cologne, 1999), p. 230.

12. On the justification of art and the discourse of art with regards to "contemporaneity," see Christian Bracht, Kunstkommentare der sechziger Jahre (Weimar, 2003) [Phil. diss.: Aachen, RWTH, 1997], especially p. 99.

13. Cf. Isabelle Graw for different (and "contemporary") interpretations of Sigmar Polke's painting. Isabelle Graw, "Beziehungsmuster bei Sigmar Polke,” Texte zur Kunst, Jhrg. 3, no. 10 (1993): 77-89, in particular pp. 82,88 .

14. Benjamin H. D. Buchloh, Gerhard Richter: Painting After the Subject of History (PhD diss., City University of New York, 1994; Ann Arbor, Michigan: UMI Dissertation Services), pp. xi-xii.

15. Jürgen Schreiber (Ein Maler aus Deutschland. Gerhard Richter. Das Drama einer Familie (Munich, Zurich, 2005), pp. 57-58, 219-220) offers information on the whereabouts of the works and the careful photographic documentation. Jeanne Nugent also pointed to the fact that during his GDR period, Richter documented his work through photographs just as carefully and intensively as later, when working in West Germany. See Jeanne Anne Nugent, "Overcoming Ideology: Gerhard Richter in Dresden, the Early Years," From Caspar David Friedrich to Gerhard Richter. German Paintings from Dresden (Los Angeles: The J. Paul Getty Museum, 2006) p. 80.

16. Dietmar Elger, Gerhard Richter, Maler (Cologne, 2002); Schreiber, Ein Maler aus Deutschland; Nugent, "Overcoming Ideology"; Christine Mehring, Jeanne Anne Nugent, and Jon L. Seydl (eds.), Gerhard Richter: Early Work, 1951-1972 (Los Angeles: The J. Paul Getty Museum, 2010).

17. Cf. Jürgen Harten, "Der romantische Wille zur Abstraktion," Gerhard Richter. Bilder-Paintings 1962-1985, exh. catalog (Düsseldorf: Städtische Kunsthalle Düsseldorf, 1986), pp. 9-62, p. 14. Richter showed his Informel paintings in 1962 in the Galerie Junge Kunst in Fulda within a group exhibition together with Manfred Kuttner, cf. Elger, Gerhard Richter, Maler, p. 51; Günter Herzog (ed.), Ganz am Anfang/Wie alles begann: Richter, Polke, Lueg \& Kuttner, sediment. Mitteilungen zur Geschichte des Kunsthandels, Heft 7 (Nuremberg, 2004), see in particular pp. 62-67.

18. It was only in 2002 that Dietmar Elgers's biography provided a number of facts on Richter's education in Dresden, which take up over forty pages of his book. Elgers, however, did not foreground the notion of a "double identity" as a theme. Instead he dedicated 
the nearly 300 remaining pages to Richter's career in West Germany. Elger, Gerhard Richter, Maler, pp. 9-43.

19. Hubertus Butin, "Gerhard Richter und die Reflexion der Bilder," in Hubertus Butin and Stefan Groner (eds.), Gerhard Richter. Editionen 1965-2004 (Ostfildern-Ruit, 2004), pp. 107-116, pp. 108-109.

20. Cf. Peter J. Schneemann, "Eigennutz. Das Interesse von Künstern am Werkkatalog," in Julia Gelshorn (ed.), Legitimationen, Künstlerinnen und Künstler als Autoritäten der Gegenwart (Bern: Peter Lang, 2005), pp. 205-221.

21. Gerhard Richter (exhibition catalog), Kunst- und Ausstellungshalle der Bundesrepublik Deuschland (Bonn, 1993, 3 vols., Ostfildern/ Ruit: Cantz, 1993, Vol. 3).

22. Erik Verhagen, "Bête comme un peintre. Les portraits de famille de Gerhard Richter," Les Cahiers du Musée national d'art moderne, no. 90, Winter 2004/5, pp. 43-60, pp. 50-51. Buchloh, who had already considered the works in relation to each other, interpreted the connection as an "integration" of Betty into the cycle. In his view, the private project commented on the failure of the public one, namely the anarchistic utopia of the removal of the separation of private and public-social fortune; Benjamin H. D. Buchloh, "Betty," in Gerhard Richter, exh. catalog, Kunst- und Ausstellungshalle der Bundesrepublik Deutschland, Bonn 1993 (Ostfildern/Ruit, 1993), vol. 2, pp. 55-57. In contrast, Stefan Germer did not see the two works in the oppositional terms of private and public, in that Richter's engagement with the RAF itself suggests a high degree of identification that is located in the private sphere, namely in the projection of his own situation onto a historical event; Stefan Germer, "Familienanschluss. Zur Thematisierung des Privaten in neueren Bildern Gerhard Richters," Texte zur Kunst, Jhrg. 7, no. 26 (1997): 109-116, 112.

23. Robert Storr, "Gerhard Richter. Forty Years of Painting," Gerhard Richter. Forty Years of Painting, exhibition catalog (New York: The Museum of Modern Art, 2002), p. 29.

24. Helmut Friedel and Ulrich Wilmes (eds.), Gerhard Richter. Atlas der Fotos, Collagen und Skizzen (Munich, 1998); Helmut Friedel (ed.), Gerhard Richter. Atlas (Cologne, 2006).

25. Gerhard Richter, "Notizen 1984" and "Notizen 1964-1965," in Hans Ulrich Obrist (ed.), Gerhard Richter. Text, Schriften und Interviews (Frankfurt am Main/Leipzig, 1993), pp. 19, 28, 32.

26. Gerhard Richter, "Notizen 1984" and "Gespräch mit Jan ThornPrikker 1989," ibid., pp. 99, 185.

27. Robert Storr, "Interview with Gerhard Richter," Gerhard Richter. Forty Years of Painting (2002), pp. 287-309, p. 289.

28. Idem, p. 289.

29. Roland Barthes, "The Death of the Author" [1968], Stephen Heath (ed.), Image, Music, Text (London: Fontana, 1977), pp. 142-148; 
Michael Foucault, "Was ist ein Autor," Schriften zur Literatur (Munich: Nymphenburger, 1974), pp. 7-31.

30. The understanding of the artist's text as a "parallel phenomenon," a term coined by Panofsky in 1920 (Erwin Panofsky, "Der Begriff des Kunstwollens" [1920], Aufsätze zu Grundfragen der Kunstwissenschaft (Berlin, 1992), pp. 29-43, pp. 32-33), gains renewed relevance here. For a more detailed consideration of Richter's verbal comments and writings, see Julia Gelshorn, "Der Künstler spricht. Vom Umgang mit den Texten Gerhard Richters," in Gelshorn (ed.), Legitimationen, Künstlerinnen und Künstler als Autoritäten der Gegenwartskunst, pp. 127-148.

31. Dieter Schwarz, "Über Aquarelle und verwandte Dinge. Gerhard Richter im Gespräch mit Dieter Schwarz” (Cologne, 26 June 1999), Gerhard Richter. Aquarelle/Watercolours 1964-1997, exh. catalog, Kunstmuseum Winterthur, Switzerland (Dusseldorf: Richter Verlag, 1999), pp. 5-16.

32. I discovered these documents via Christof Lichtin, who studied them from a different perspective for his dissertation on the artist's interview. This work has now been published: Christoph Lichtin, Das Künstlerinterview. Analyse eines Kunstprodukts (Bern, Berlin, Frankfurt am Main a.o.: Peter Lang, 2004) [Lizentiatsarbeit: Universität Bern, 2001].

33. On the interview as a construct, see Iwona Blazwick, "An Anatomy of the Interview," Art Monthly, no. 200 (1996): 15-16, especially p. 16, and Lichtin, Das Künstlerinterview, p. 116.

34. Peter Bürger, Theorie der Avantgarde (Frankfurt am Main: Suhrkamp Verlag, 1974).

35. Benjamin H. D. Buchloh, "Readymade, photographie et peinture dans la peinture de Gerhard Richter," Gerhard Richter, exh. cata$\log$ (Paris: Musée national d'art modern, Centre national d'art et de culture Georges Pompidou, 1977), pp. 11-17; Benjamin H. D. Buchloh, Gerhard Richter: Painting after the Subject of History $(\mathrm{PhD}$ Dissertation, City University of New York, 1994).

36. Sven-Olov Wallenstein, "The Face of Necessity. History and Freedom in the Work of Gerhard Richter," Material. Journal of Contemporary Art, year 29 (summer 1996): 8.

37. Butin, "Gerhard Richter und die Reflexion der Bilder," p. 13.

38. Arnold Gehlen, Einblicke (Frankfurt am Main: Klostermann, 1975), pp. 115-132.

39. See Jean-François Lyotard, La condition postmoderne (Paris: Minuit, 1979); Fredric Jameson, Postmodernism or, The Cultural Logic of Late Capitalism (Durham, NC: Duke University Press, 1991), pp. 1-54.

40. Wolfgang Welsch, Unsere postmoderne Moderne (Weinheim, 1988), pp. 17-18.

41. See especially Alexandre Kojève, Hegel, Eine Vergegenwärtigung seines Denkens. Kommentare zur Phänomenologie des Geistes, 
edited by Iring Fetscher (Stuttgart: Kohlhammer, 1958); Lutz Niethammer, Posthistorie. Ist die Geschichte zu Ende? (Reinbek, Hamburg: Rowohlt, 1989), pp. 73-82.

42. Horst Bredekamp, "Metaphern des Endes im Zeitalter des Bildes," Heinrich Klotz (ed.), Kunst der Gegenwart, Museum für Neue Kunst (Munich, New York, 1997), pp. 32-37, in particular pp. 32-33.

43. Arthur C. Danto, "Das 'Ende der Kunst' missverstanden als 'Tod der Malerei,"” Anne-Marie Bonnet and Gabriele Kopp-Schmidt (eds.), Kunst obne Geschichte? Ansichten zur Kunst und Kunstgeschichte heute (Munich: Beck, 1995), p. 76.

44. Ibid., pp. 75-77.

45. Ibid., p. 75; Arthur C. Danto, Das Fortleben der Kunst (Munich: Fink, 2000), pp. 74, 155

46. Douglas Crimp, "Das Ende der Malerei" [1981], in Über die Ruinen des Museums. Das Museum, die Fotografie und die Postmoderne (Dresden: Verlag der Kunst, 1996), pp. 100-122; also cf. Crimp, "Pictures" [1979], Brian Wallis (ed.), Art After Modernism. Rethinking Representation (New York: The Museum of Contemporary Art, 1984), pp. 175-188; Douglas Crimp, “Die Fotografische Aktivität des Postmodernismus" and "Das Aneignen der Aneignung," Über die Ruinen des Museums, pp. 123-140 and pp. 141-154.

47. Craig Owens, "From Work to Frame, or Is there Life After on, 'The Death of the Author'?", C. Owens, Beyond Recognition, Representation, Power and Culture (edited by Scott Bryson et al.) (Berkeley and Los Angeles, Berkeley: University of California Press, 1992), pp. 122-139, pp. 123-125.

48. Gerhard Richter, Übersicht, exh. catalog, Institut für Auslandsbeziehungen e. V., Stuttgart (Cologne: König, 2000), p. 10.

49. Danto, Das Fortleben der Kunst, p. 32.

50. Jeanne Anne Nugent, "Overcoming Ideology: Gerhard Richter in Dresden, the Early Years," From Caspar David Friedrich to Gerhard Richter. German Paintings from Dresden, catalog (Los Angeles: The J. Paul Getty Museum, 2006), p. 79.

51. Cf. Ulrich Wilmes (ed.), Presseberichte: Gerhard Richter. 18 Oktober 1977 (Frankfurt am Main/Cologne, 1986); on the reception of the cycle in Germany and internationally, see Hubertis Butin, Zu Richters Oktober-Bildern (Cologne: König, 1991), especially pp. 32-42.

52. Gerhard Richter. October 18, 1977, catalog (New York: The Museum of Modern Art, 2000); Storr, "Gerhard Richter. Forty Years of Painting."

53. Storr, "Gerhard Richter. Forty Years of Painting," p. 37.

54. Wolfgang Max Faust and Gerd de Vries, Hunger nach Bildern. Deutsche Malerei der Gegenwart (Cologne: Dumont, 1982); cf. Lucius Grisebach, "Es wird wieder gemalt!," 1945-1985. Kunst in 
der Bundesrepublik Deutschland, catalog (Berlin: Neue Nationalgalerie Berlin, 1985), pp. 322-329.

55. Deutschlandbilder. Kunst aus einem geteilten Land, catalog, Martin-Gropius-Bau, Berlin (Cologne: Dumont, 1997).

56. Gerhard Richter. 18. Oktober 1977, catalog, Museum Haus Esters (Krefeld, 1999); Butin, Zu Richters Oktober Bildern; Gerhard Richter. October 18, 1977, catalog (New York: The Museum of Modern Art, 2000).

57. Elger, Gerhard Richter, Maler; Hubert Butin, "Gerhard Richer und Sigmar Polke. Eine Künstlerfreundschaft als mikrosoziales System," Julia Gelshorn (ed.), Legitimationen, Künstlerinnnen und Künstler als Autoritäten der Gegenwartskunst, pp. 43-60; Herzog (ed.), Ganz am Anfang; cf. Nugent, "Overcoming Ideology: Gerhard Richter in Dresden, the Early Years."

58. Benjamin H. D. Buchloh, "Gerhard Richters Atlas. Das anomische Archiv," Herta Wolf (ed.), Paradigma Fotografie. Fotokritik am Ende des fotografischen Zeitalters (Frankfurt am Main: Suhrkamp Verlag 2002), pp. 419-423.

59. Ibid., p. 418.

60. Storr, "Gerhard Richter. Forty Years of Painting," pp. 40-41.

61. Ibid., p. 41.

62. Schreiber, Ein Maler aus Deutschland. Gerhard Richter.

63. Ibid., p. 246.

64. Ibid., pp. 12-14; Suzanne Page and Hans Ulrich Olbrist (eds.), Gerhard Richter: War Cut (Cologne: König, 2004).

65. Schreiber, Ein Maler aus Deutschland. Gerhard Richter, p. 164.

66. See Stefan Gronert, "Das Porträt des Abbilds," Gerhard Richter. Portraits, catalog, Museumsberg Flensburg (Hatje Cantz Verlag, 2006), pp. 88-89.

67. Also see the text for the 2004 exhibition Mythen der Nationen in the Deutsche Historische Museum, which included Richter's painting Onkel Rudi. According to this text, Gerhard Richter's picture addresses a problem that hitherto has never been debated; and Richter not only reminds us that the members of the Wehrmacht participated in war crimes, but that our own uncle might have been involved. See also Schreiber, Ein Maler aus Deutschland. Gerhard Richter, pp. 241-242.

68. Jürgen Becker, "Die Warteschleifen der Erinnerung," Gerhard Richter im Albertinum Dresden, catalog, Galerie Neue Meister im Albertinum (Dresden, 2004), p. 94.

69. In a (hitherto unpublished) dissertation, Jeanne Anne Nugent has analyzed the early phases of Richter's oeuvre, focusing in particular on the issue of an east, west, or pan-German art; Jeanne Ann Nugent, Family Album and Shadow Archive: Gerhard Richter's East, West and All German Painting, 1949-1966 (University of Pennsylvania, 2005). 